\title{
Improving knowledge on Viviania linostigma R.Knuth (Francoaceae), a threatened species from southern Brazil
}

\author{
Ampliando o conhecimento sobre Viviania linostigma R.Knuth \\ (Francoaceae), uma espécie ameaçada de extinção do sul do Brasil
}

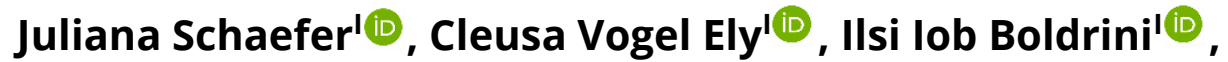 Sérgio Augusto de Loreto Bordignon"(i)}

\author{
' Universidade Federal do Rio Grande do Sul, Porto Alegre, RS, Brazil \\ "Universidade La Salle, Canoas, RS, Brazil
}

\begin{abstract}
Viviania linostigma is restricted to the Brazilian territory, considered a threatened and endemic species of a small region in the Araucaria Forest. This species has been recorded only in southeast Santa Catarina State and the extreme northeast of Rio Grande do Sul State, Brazil. Here, we report four new records of V. linostigma for Rio Grande do Sul, expanding its known distribution by $262 \mathrm{~km}$ to the south and improving knowledge about the conservation status of the species. These novelties reinforce that species conservation requires more investment in fieldwork, especially in little sampled regions.
\end{abstract}

Keywords: Araucaria Forest; Brazilian flora; IUCN

\section{RESUMO}

Viviania linostigma é restrita ao território brasileiro, considerada uma espécie ameaçada e endêmica de uma pequena região da Floresta de Araucária. Essa espécie tem sido registrada apenas no sudeste de Santa Catarina e no extremo nordeste do estado do Rio Grande do Sul, Brasil. Aqui, relatamos quatro novos registros de V. linostigma para o Rio Grande do Sul, expandindo sua distribuição conhecida em 262 $\mathrm{km}$ ao sul e ampliando o conhecimento sobre o estado de conservação da espécie. Essas novidades reforçam que a conservação de espécies requer mais investimento em trabalhos de campo, especialmente em regiões pouco amostradas.

Palavras-chave: Floresta de Araucária; Flora brasileira; IUCN 


\section{INTRODUCTION}

Brazil has the most diverse flora of the Americas, with 34,766 vascular plant species, 55\% of them endemic (ULLOA ULLOA et al., 2017; FLORA DO BRASIL, 2020). However, with only 0.59 plant specimens collected per $\mathrm{km}^{2}$, the Brazilian flora is still far from satisfactorily known (SOBRAL AND STEHMANN, 2009). Collected materials are mostly charismatic species from iconic or protected areas, with a geographical bias towards areas around large urban centers or with good accessibility in general, especially in the coastal region (NERVO; WINDISCH; LORSCHEITTER, 2010; POSSINGHAM; BALL; ANDELMAN, 2000).

The Atlantic Forest domain covers 15\% of the Brazilian territory and includes a variety of ecosystems such as highland grasslands, forests, restingas, marshes, as well as coastal and oceanic islands (BOND-BUCKUP AND DRELER, 2010). In southern Brazil, mosaics of Campos (grasslands) and Araucaria Forest shape the Atlantic Forest landscapes (BEHLING AND PILLAR, 2007). In the Rio Grande do Sul (RS) State, biodiversity inventories carried out in the Araucaria Forest are mainly concentrated in protected areas of São Francisco de Paula municipality (CAPORAL AND EGGERS, 2005; FERREIRA AND EGGERS, 2008; ISERHARD et al., 2010; CAPPELATTI AND SCHIMIDT, 2011), which stresses the poor collection efforts made in this region.

Vivianiaceae, as previously accepted (APG III, 2009), is restricted to South America, occurring in Chile, Argentina, Uruguay, and in the southern half of Brazil (LEFOR, 1975; FLORA DO BRASIL, 2020). Recently, Vivianiaceae was included in Francoaceae (APG IV, 2016), which is why we follow here this new classification. Most species of Viviania occur in central-southern Chile, where the genus is more diverse (PALAZZESI, 2007). In Brazil, only two species of Viviania are recognized: $V$. albiflora (Cambess.) Reiche and V. linostigma R.Knuth (FERREIRA, 2020). Viviania albiflora is a widespread species that occurs in several Brazilian states, besides the Argentine and Uruguayan territories (FERREIRA, 2020). On the other hand, $V$. 
linostigma is an endangered species (VU), considered endemic to the Serra Geral, where it was only known for southeastern Santa Catarina and the extreme northeast of RS (FERREIRA et al., 2016). Here, we present four new records of $V$. linostigma from the Araucaria Forest in RS, increasing its known distribution by 262 $\mathrm{km}$ to the south, and use the updated distribution data to reassess its conservation status.

\section{MATERIAL AND METHODS}

The study was based on field expeditions and a literature review. Specimens' identification was confirmed through the analysis of the protologue, type specimens available in the Kew $(K)$ virtual herbarium, and specialized literature (FERREIRA et al., 2016). Vouchers were incorporated into the ICN herbarium (THIERS, continuously updated). A distribution map was constructed in the software Quantum Gis v. 2.18, using WGS-84 datum. GeoCAT webtool (BACHMAN et al., 2011) was used to reevaluate the conservation status of $V$. linostigma, following Red List Criteria (IUCN 2012, 2019).

\section{RESULTS}

Viviania linostigma R.Knuth, Pflanzenr: 4 (129): 573, 1912. इ Linostigma petiolatum Klotzsch, Linnaea, 10: 439, 1836. (Adapted from FERREIRA et al., 2016)

Prostrate herb, with sprawling stems, usually radicant in the lower nodes. Stems subcylindrical, hirsute. Leaves opposite, petiolate, petiole $0.2-1.3 \mathrm{~cm}$ long, pilose. Leaf 1-2.7 $\times 1-2.6 \mathrm{~cm}$, generally as wide as long, ovate to broadly ovate, orbicular, base truncate, subcordate, less commonly obtuse, margins crenate, dark green adaxially, with sparse pubescence between the veins, abaxially albotomentose. Flowers tetramerous, arranged mainly in the axils of the upper nodes, in groups of 3 per node, subtended by four leaves. Calyx tomentose, campanulate, 
sepals fused, calyx lobes acute. Petals light pink to white, obtriangular, apex crenate. Stamens 8 , nectary glands alternating with two series of stamens, 4 as long as the sepals and 4 shorter than sepals. Ovary 2 -locular, trichomes concentrated at the apex of the ovary. Fruit a capsule, hirsute.

Habitat: Viviania linostigma is associated with Araucaria Forest (Fig. 1), preferentially at forest edges and humid environments.

Figure 1 - Geographic distribution of Viviania linostigma. A. Viviania linostigma in Passa Sete municipality (roadside). B. Habitat of Viviania linostigma converted to a soybean crop. C-D. Viviania linostigma at the religious tourist point of Passa Sete municipality

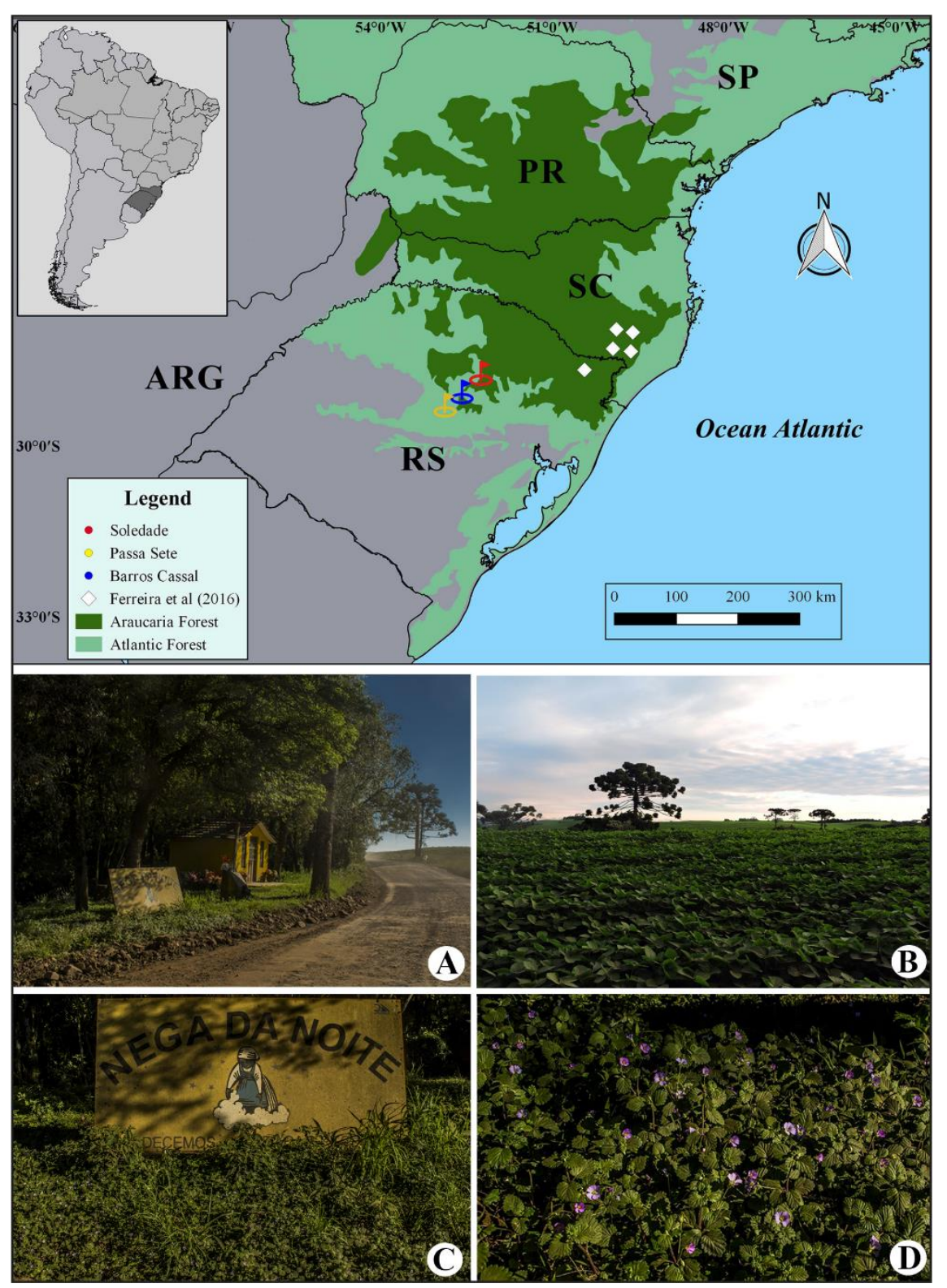

Ci. e Nat., Santa Maria, v.43, e24, 2021 
Comments: The three municipalities of RS where $V$. linostigma was newly recorded (Barros Cassal, Soledade and Passa Sete) are characterized by rather small-scale agriculture. In Passa Sete, for example, V. linostigma grows in sympatry with V. albiflora at a religious site in Campo do Sobradinho, adjacent to a soybean crop (Fig. 1A-D).

Examined Material: Brazil. RIO GRANDE DO SUL: Bom Jesus, entre Bom Jesus e Rio Pelotas, E. Pereira 6422 \& Pabst 6249, 23 October 1961 (RB 115531, image

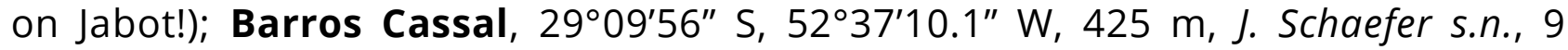
February 2019 (ICN 200676!); 2909'24.3" S, 52³9'37.6" W, 419 m, J. Schaefer s.n., 9 February 2019 (ICN 200677!); Passa Sete, Campo do Sobradinho, 29²4'41.2" S 52 55'08.6" W, 597 m, R. Rigon s.n., 10 October 2018 (ICN 199776!); Soledade, $28^{\circ} 51^{\prime} 14.00^{\prime \prime}$ S, 52²3'9.00" W, 686 m, S.A.L. Bordignon \& M. Grings s.n., 20 September 2018 (ICN 200110!). SANTA CATARINA: Bom Jardim da Serra, Aparados da Serra, Serra do Oratório, R. Reitz \& R.M. Klein 6986, 21 August 1958 (L.2007788, image on SpeciesLink!; PACA 65209, photo!; HBR, n.v.); Urubici, Parque Nacional de São Joaquim, R. Trevisan 1423, 8 December 2013 (FLOR 51308, image on SpeciesLink!); Parque Nacional de São Joaquim, R. Trevisan 1716, 3 December 2015 (FLOR 59153, image on SpeciesLink!); Parque Nacional de São Joaquim, L.A. Funez, D.H. Costa-Rezende, W. Ribeiro-Nardes, M. Comin 8196, 10 November 2018 (FLOR 67059, image on SpeciesLink!).

Table 1 - Morphological differences between V. albiflora and V. linostigma

\begin{tabular}{lcc}
\hline & \multicolumn{1}{c}{ V. albiflora } & V. linostigma \\
\hline Leaves & lanceolate, sessile or petiolate & $\begin{array}{c}\text { ovate to broadly ovate, sometimes } \\
\text { Fig. 2D }\end{array}$ \\
orbiculate, always petiolate Fig. 2B-C \\
Petals & 5 & 4 \\
Stamens & 5, with obtuse apex Fig. 2D-E & 4, with crenate apex Fig. 2A-C \\
Ovary/ Ovules & 10 & 8 \\
\hline
\end{tabular}

Font: Adapted from FERREIRA et al., 2016 
Figure 2- A-C. Viviania linostigma. A. Tetramerous flowers. B. Ovate to broadly ovate or orbicular leaves. C. Prostrate habit. D-E. Viviania albiflora. D. Lanceolate leaves and pentamerous flowers. E. Fertile branch
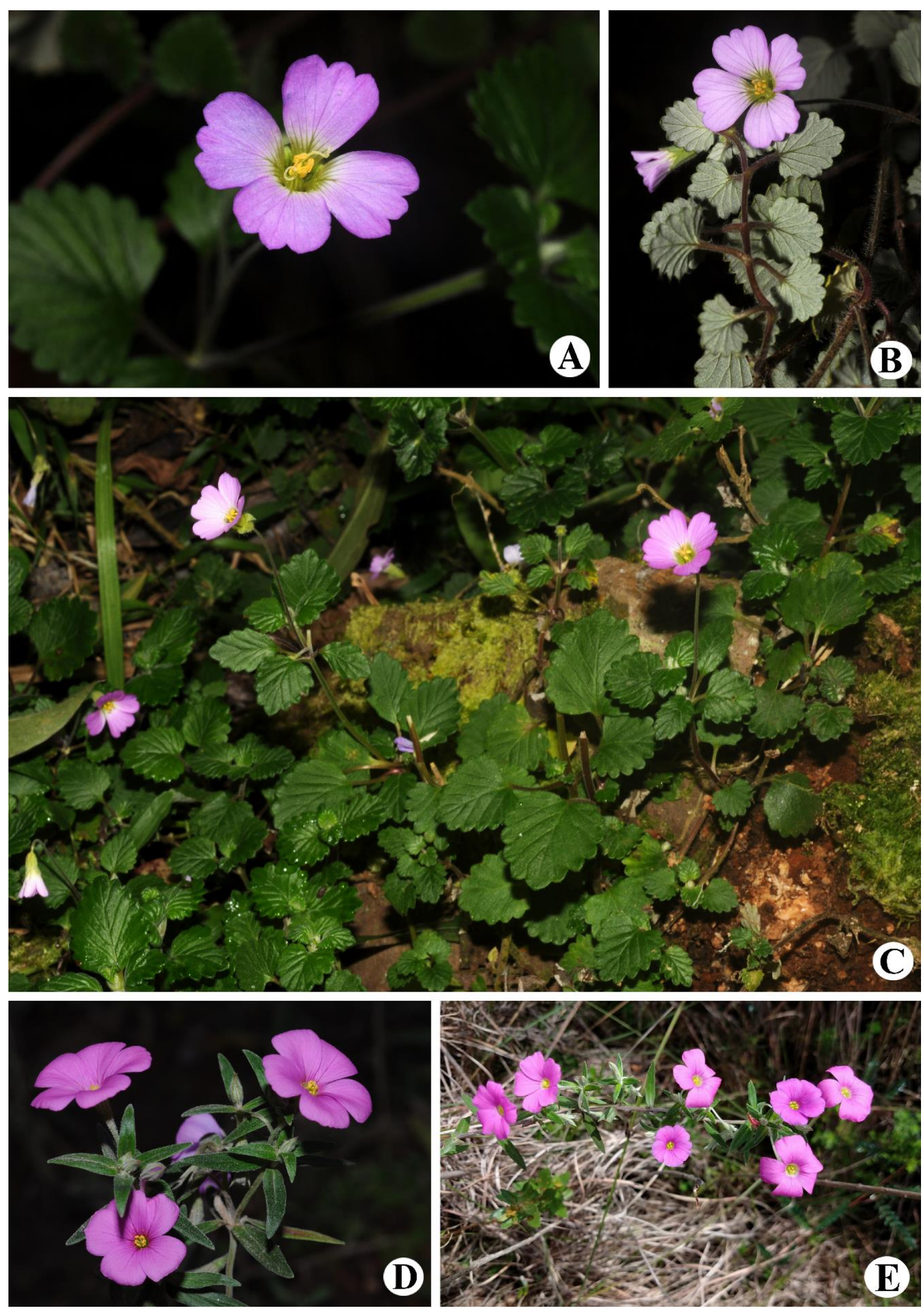

Ci. e Nat., Santa Maria, v.43, e24, 2021 


\section{DISCUSSION}

Viviania linostigma was initially described as Linostigma petiolatum Klotzsch, and later synonymized with Viviania albiflora, of which it may be easily distinguished (see Table 1; FERREIRA et al., 2016, 2020). In 2016, V. linostigma was reestablished as a distinct taxon by FERREIRA et al. (2016), who also indicated it as a species of elevated conservation concern. Although these authors have not mentioned potential threats nor explored other aspects justifying its conservation status, $V$. linostigma was assessed as Vulnerable based on the IUCN criterion that deals with the geographic range (B criterion).

Our findings show that $V$. linostigma is not restricted to the Aparados da Serra Geral, as previously assumed (FERREIRA et al., 2016, 2020), but has a wider distribution in the southern part of the Araucaria Forest region (Fig. 1). The increase in the known distribution of $V$. linostigma, about $262 \mathrm{~km}$ to the south, required a revaluation of its conservation status, given the previous categorization was based on a smaller Area of Occupancy (AOO). Furthermore, V. linostigma was newly recorded in highly fragmented landscapes, in which the main threat to these southern subpopulations appears to be land-use change, mainly by soybean and tobacco cultivation. Transition zones between ecosystems are often considered of low conservation importance and overlooked in research. Nevertheless, as shown here, small fragments might reveal unexpected occurrences of rare or threatened species. Cataloging the diversity extensively can help us to fulfill collection gaps and refine our understanding of conservation priorities within the Atlantic Forest and other ecosystems (VOGEL ELY AND BOLDRINI, 2015; HASSEMER et al., 2015; LUBER et al., 2016).

Fieldwork is essential to describe and understand ecosystems, serving as support for policy decision-making on biodiversity conservation (DIJKSTRA, 2016). Unfortunately, the lack of funding and incentives for this kind of study is a known problem (VOGEL ELY et al., 2017; MENEZES et al., 2018, SALDAÑA et al., 2018). Even 
so, we emphasize that an investment in sampling efforts, especially in Araucaria Forest, is necessary to ensure effective conservation actions for endangered species such as $V$. linostigma.

\section{ACKNOWLEDGMENTS}

We thank Romar Rigon for the collection of $V$. linostigma in the municipality of Passa Sete, and for his beautiful photographic records. Thanks also go to the biologist Mateus Beise for providing the geographic coordinates of some records in Barros Cassal. This study was financed in part by the Coordenação de Aperfeiçoamento de Pessoal de Nível Superior (CAPES) - Finance Code 001. Authors also thank Conselho Nacional de Pesquisas e Desenvolvimento Tecnológico (CNPq 310133/2017-3) for supporting field expeditions.

\section{REFERENCES}

APG III. An update of the Angiosperm Phylogeny Group classification for the orders and families of flowering plants. APG III. Botanical Journal of the Linnean Society. 2009; 161: 105-121. doi: 10.1111/j.1095-8339.2009.00996.x

APG IV. Na update of the Angiosperm Phylogeny Group classification for the orders and families of flowering plants: APG IV. Botanical Journal of the Linnean Society. 2016; 181: 1-20. doi: 10.1111/boj.12385

BACHMAN S, MOAT J, HILL AW, DE LA TORRE J, SCOTT B. Supporting Red List threat assessments with GeoCAT: geospatial conservation assessment tool. ZooKeys. 2011; 126: 117-126. doi: 10.3897/zookeys.150.2109

BEHLING H, PILLAR VP. Late Quaternary vegetation, biodiversity and fire dynamics on the southern Brazilian highland and their implication for conservation and management of modern Araucaria Forest and grassland ecosystems. Philosophical Transactions of the Royal B. Society. 2007; 362: 243-251. doi: 10.1098/rstb.2006.1984

BOND-BOCKUP G, DRELER C. Desvendando a região In: Biodiversidade dos Campos de Cima da Serra. Porto Alegre: Libretos; 2010. p. 11-17.

CAPPELATTI L, SCHMIDT JL. Flora arbórea de área de floresta ombrófila mista em São Francisco de Paula, RS, Brazil. Pesquisas, Botânica. 2011; 62: 253-261. 
CAPORAL FJM, EGGERS L. Poaceae na área do Centro de Pesquisas e Conservação da Natureza Pró-Mata, São Francisco de Paula, Rio Grande do Sul, Brasil. Iheringia. 2005; 60, 141-150.

DIJKSTRA KDB. Restore our sense of species. Nature. 2016; 533, 172-174.

FERREIRA PAM, EGGERS L. Espécies de Cyperaceae do Centro de Pesquisa e Conservação da Natureza Pró-Mata, município de São Francisco de Paula, RS, Brasil. Acta Botanica Brasilica. 2008; 22, 173-185. doi: 10.1590/S0102-33062008000100018

FERREIRA JPR. Vivianiaceae in Flora do Brasil 2020. Jardim Botânico do Rio de Janeiro. Available from: http://www.floradobrasil.jbrj.gov.br/reflora/floradobrasil/FB249 Accessed in: 10 Abr. 2021

FERREIRA JPR, HASSEMER G, CAMPESTRINI S, WEIGEND M, TREVISAN R. A revision of the extraAndean Vivianiaceae. Phytotaxa. 2016; 246(1): 23-36. doi: 10.11646/phytotaxa.246.1.2

FLORA DO BRASIL 2020. Jardim Botânico do Rio de Janeiro. Available from: http://floradobrasil.jbrj.gov.br/ Accessed in: 06 Mar. 2021

HASSEMER G, FERREIRA PMA, TREVISAN R. A review of vascular plant endemisms in Santa Catarina, southern Brazil, highlights critical knowledge gaps and urgent need of conservation efforts. The Journal of the Torrey Botanical Society. 2015; 142:78-95. doi: 10.3159/TORREY-D14-00033.1

ISERHARD CA, QUADROS MT, ROMANOWSKI HP, MENDONÇA JR MS. Borboletas (Lepidoptera: Papilionoidea e Hesperioidea) ocorrentes em diferentes ambientes na Floresta Ombrófila Mista e nos Campos de Cima da Serra, Brasil. Biota Neotropica. 2010; 10(1): 309-320. doi: 10.1590/S1676-06032010000100026

IUCN 2012. IUCN Red List Categories and Criteria. Version 3.1. Second edition. Prepared by the Standards and Petitions Subcommittee. Gland, Switzerland and Cambridge, UK: IUCN. iv + 32pp. Available from: https://www.iucnredlist.org/resources/categories-and-criteria Accessed in: 18 Nov. 2019

IUCN 2019. Guideline for Using the IUCN Red List - Categories and Criteria. Version 14. Prepared by the Standards and Petitions Subcommittee. Available from: http://www.iucnredlist.org/documents/RedListGuidelines.pdf Accessed in: 18 Nov. 2019

LEFOR MW. A taxonomic revision of the Vivianiaceae. The University of Connecticut Occasional Papers - Biological Science Series. 1975; 2(15): 225-255.

LUBER J, TULER AC, TORRES F, CHRIST JA, GUIDONI-MARTINS KG, ZANETTI M, HOLLUNDER RK, MANHÃES VC, ZORZANELLI JPF, MENDONÇA ES, GARBIN ML, CARRIJO TT. List of Angiosperms species in an Atlantic Forest fragment reveals collection gaps in Espírito Santo state, Brazil. CheckList. 2016; 12(1): 1835 doi: 10.15560/12.1.1835 
MENEZES L. DA S, VOGEL ELY C, LUCAS DB, MINERVINI SILVA GH, BOLDRINI II, OVERBECK GE. Plant species richness record in Brazilian Pampa grassland sand implications. Brazilian Journal of Botany 2018. doi: 10.1007/s40415-018-0492-6

NERVO MH, WINDISCH PG, LORSCHEITTER ML. Representatividade da Base Amostral da Pteridoflora do estado do Rio Grande do Sul (Brasil) e novos registros de distribuição. Pesquisas, Botânica. 2010; 61: 245-259.

PALAZZESI L, GOTTSCHLING M, BARREDA V, WEIGEND M. First Miocene fossils of Vivianiaceae shed new light on phylogeny, divergence time, and historical biogeography of Geraniales. Biological Journal of the Linnean Society. 2012; 107: 67-85. doi: 10.1111/j.10958312.2012.01910.x

POSSINGHAM H, BALL I, ANDELMAN S. Mathematical methods for identifying representative reserve networks. In Quantitative methods Conservation Biology; 2000; New York. p. 291-305.

SALDAÑA AR, DELIBES-MATEOS M, FERREIRA C. Are fieldwork studies being relegated to second place in conservation science? Global Ecology and Conservation. 2018; 14: 1-6. doi: 10.1016/j.gecco.2018.e00389

SOBRAL M, STEHMANN J. An analysis of new angiosperm species discoveries in Brazil. Taxon. 2009; 58(1): 227-232.

THIERS, B [continuously updated]. Index Herbariorum: a global directory of public herbaria and associated staff. New York Botanical Garden's Virtual Herbarium. Available from: http://sweetgum.nybg.org/science/ ih/ Accessed in: 18 Nov. 2019

ULLOA ULLOA C, ACEVEDO-RODRIGUEZ P, BECK S, BELGRANO MJ, BERNAL R, BERRY PE, BRAKO L, CELIS M, DAVIDSE G, FORZZA RC, GRADSTEIN SR, HOKCHE O, LEÓN B, LEÓN-YÁNEZ S, MAGILL RE, NEILL DA, NEE M, RAVEN PH, STIMMEL H, STRONG MT, VILLASEÑOR JL, ZARUCCHI JL, ZULOAGA FO, JØRGENSEN PM. An integrated assessment of the vascular plant species of the Americas. Science. 2017; 358: 1614-1617. doi: 10.1126/science.aao0398

VOGEL ELY C, BOLDRINI II. Two new records of endemic and endangered angiosperms in Santa Catarina, Brazil. CheckList. 2015; 11: 1-5. doi: 10.15560/11.6.1812

VOGEL ELY C, BORDIGNON SAL, TREVISAN R, BOLDRINI II. Implications of poor taxonomy in conservation. Journal for Nature Conservation. 2017; 36: 10-13 doi: 10.1016/j.jnc.2017.01.003 


\section{Authorship Contribution}

\section{1 - Juliana Schaefer}

Doutoranda em Botânica

https://orcid.org/0000-0001-9967-7115 - julianaschaeferbio@gmail.com

Contribution: Conceptualization, Investigation, Writing - Draft, Writing - review \& editing

\section{2 - Cleusa Vogel Ely}

Doutora em Botânica

https://orcid.org/0000-0001-9094-9524 - cleusavely@gmail.com

Contribution: Conceptualization, Investigation, Writing - review \& editing

\section{3 - Ilsi lob Boldrini}

Doutora em Zootecnia

https://orcid.org/0000-0003-1028-8864 - ilsi.boldrini@ufrgs.br

Contribution: Supervision, Writing - review \& editing

\section{4 - Sérgio Augusto de Loreto Bordignon}

Doutor em Ciências Farmacêuticas

https://orcid.org/0000-0001-5041-1148 - sergio.bordignon@unilasalle.edu.br

Contribution: Investigation, Writing - review \& editing

\section{How to quote this article}

SCHAEFER, J.; VOGEL ELY, C.; BOLDRINI, I. I.; BORDIGNON, S. A. L. Improving knowledge on Viviania linostigma R.Knuth (Francoaceae), a threatened species from southern Brazil. Ciência e Natura, Santa Maria, v. 43, e24, p. 1-11, 2021. DOI 10.5902/2179460X40837. Available from: https://doi.org/10.5902/2179460X40837. Accessed: Month Abbreviated. day, year. 